\title{
Helsekonsekvenser av vektendring - er slanking fordelaktig? En litteraturoversikt
}

\author{
Anne Johanne Søgaard \\ Senter for forebyggende medisin, Ullevål sykehus \\ Korrespondanse: Institutt for allmennmedisin og samfunnsmedisinske fag, Seksjon for epidemiologi, Postboks 1130, Blindern, 0318 Oslo \\ Telefon: 22850649 telefax: 22850620 e-post: a.j.sogaard@samfunnsmed.uio.no
}

\begin{abstract}
SAMMENDRAG
Langsom vektøkning gjennom livet inntil kroppsmasseindeks (KMI) 27 ser ikke ut til å gi særlige negative utfall mht. total dødelighet. En økning på $\geq 20 \mathrm{~kg}$ fra 18 års alder er trolig negativt - det samme er vektøkning ut fra en høy utgangsvekt. Selv om mange studier finner økt dødelighet hos yngre og middelaldrende personer med KMI $>27$, er det foreløpig ingen studier som har vist at vektreduksjon blant friske overvektige personer gir økt levetid. Flere studier viser tvert imot en assosiasjon mellom vektreduksjon og økt dødelighet. Heller ikke studier som prøver å begrense analysene til personer med frivillig vekttap, finner redusert dødelighet etter vektreduksjon blant friske overvektige individer. Noen få studier har vist redusert dødelighet blant overvektige personer med etablerte sykdommer eller høy risiko for hjerte-karsykdom og diabetes. Når det gjelder sykelighet har de fleste studier enten ikke funnet noen assosiasjon mellom vektreduksjon og sykelighet, eller funnet $ø k t$ sykelighet. Unntaket er diabetes, der vekttap i enkelte studier samvarierer med redusert sykelighet. Det er i mange studier funnet sammenheng mellom vekttap og økt risiko for lårhalsbrudd og gallesten. De fleste studier har imidlertid vist at moderat vektreduksjon (vekttap på opp til 10\%) fører til redusert blodtrykk, forbedret glukosekontroll, redusert kolesterolnivå, forbedret dyslipidemi, forbedret lungefunksjon, bedre søvnkvalitet og redusert søvnapnè. Moderat vekttap vil også kunne lindre leddsmerter. Dette tilsynelatende paradoks diskuteres i artikkelen - bl.a. drøftes de metodeproblemer som er innebygget i mange av studiene. Fordi det har vist seg vanskelig for personer med kraftig overvekt å redusere vekten permanent - og fordi resultatene mht. helseeffektene av vektreduksjon er usikre, bør hovedinnsatsen settes inn i forhold til å forebygge overvekt/fedme overfor enkeltpersoner med potensielle problemer. Personer med etablerte vektrelaterte sykdommer bør tilbys behandling. Det forebyggende arbeidet bør ellers fokusere på å endre strukturelle forhold i samfunnet - slik som lettere tilgang til sunn mat til en "sunn" pris - og økte muligheter for og oppmuntring til fysisk aktivitet $i$ dagliglivet.
\end{abstract}

Søgaard AJ. The health consequences of weight change - is losing weight worth while? Nor J Epidemiol 2000; 10 (1): 95-108.

\section{ENGLISH SUMMARY}

Both very lean and very obese individuals seem to have increased morbidity and mortality, but there is only a slight increase in the risk of mortality within 9 units of body mass index (BMI $\left.=\mathrm{kg} / \mathrm{m}^{2}\right)$ - between BMI 19 and 27. Evidence suggests that weight gain throughout life until BMI 27 do not increase mortality. But $20 \mathrm{~kg}$ and more weight gain from 18 years old is negative, the same is weight gain from a high weight at the age of 18 . For some diseases such as osteoporotic fractures, the risk decreases with weight gain and high BMI. Weight cycling may be an independent risk factor for mortality and morbidity, but the evidence is insufficient for the time being. Even granting the existence of an association between increasing BMI and higher mortality, it does not follow that losing weight will reduce the risk. Although intentional weight loss results in improvements in glycaemic control, dyslipidaemia and hypertension, the majority of studies fail to support the notion that weight loss reduces mortality rates. Our knowledge is, however, mainly based on observational studies, which often have methodological flaws and limitations. This and other possible explanations for the apparent paradox, that weight loss do associate with favorable values on risk factors for cardiovascular disease and diabetes mellitus, but not with reduced morbidity and mortality, are discussed in this paper. Because of the lack of evidence supporting the long-term effectiveness of weight reduction methods and because weight reduction probably is not without risks, obese healthy individuals should rather prevent further weight gain than trying to reduce weight. For obese individuals with weight-related diseases (e.g. diabetes mellitus and hypertension), weight reduction might be recommended because it can alleviate symptoms and reduce drug therapy requirements, at least in the short term. The main effort in the future should be to force the food industry to produce more healthy and inexpensive food, increase the availability of this food, and encourage the society at large to give "the everyday" physical activity better possibilities and opportunities. 


\section{INNLEDNING}

Gjennomsnittsvekten blant norske ungdommer har trolig steget de senere årene, men vi har relativt sparsomt med longitudinelle data (SEF-rapport, 2000). Vi vet med større sikkerhet at både vekten og kroppsmasseindeksen $\left(\mathrm{KMI}=\mathrm{kg} / \mathrm{m}^{2}\right)$ har økt blant voksne (20-60 år) de siste 30 årene. Økningen i andelen som har KMI > 30 (fedme) har også økt i dette tidsrommet, mer blant yngre enn eldre - og mer blant menn enn kvinner (SEF-rapport, 2000). Denne vektøkningen betegnes av enkelte som en epidemi, og anses å være et økende problem i store deler av den vestlige verden og i deler av utviklingslandene (WHO-report, 1998). Norge ligger foreløpig trolig bedre an mht. overvekt enn mange andre befolkningsgrupper. En europeisk studie av 17000 personer viste at norske kvinner og menn er høyere og tynnere enn tilsvarende østeuropeere, vesteuropeere og sydeuropeere i alle aldre, unntatt kvinner 50-59 år (EVOS- studien) (Meyer et al., 1995a). Dobbelt så mange nordmenn hadde KMI $<22$ sammenlignet med resten av Europa $(11,1 \%$ vs. 6,6\% for menn, $19,2 \%$ vs. 9,9\% for kvinner). Man frykter imidlertid at vektutviklingen i Norge skal følge utviklingen $\mathrm{i}$ andre land (SEF-rapport, 2000).

Sammenhengen mellom vekt og helse har vært undersøkt i utallige studier, og ulike mål på kroppsstørrelse er benyttet - slik som vekt, kroppsmasseindeks (KMI), prosent av gjennomsnittsvekt, prosent fettmasse, livvidde, liv-hofte-ratio osv. Det mest vanlige har vært å studere assosiasjonen mellom KMI og ulike endepunkter for helse. De senere år har flere studier også rapportert vektøkning, vektreduksjon og vektfluktuasjon ("weight cycling") i løpet av et visst tidsrom, som selvstendige og uavhengige faktorer med betydning for helse.

Denne oversikten vil, etter en kort innledning om assosiasjonen mellom KMI og dødelighet, fokusere på helsekonsekvensene av vektendring - med særlig vekt på konsekvensene av vektreduksjon.

\section{METODE FOR DATASØK - OG AVGRENSNING}

Undersøkelsene som er omtalt i denne artikkelen er funnet vha. ulike metoder:

- Søk i databasene MEDLINE og BIBSYS. Referanselistene til innhentede artikler fra disse databasene ble også gjennomgått.

- Referanser fra WHO-rapporten: Obesity. Preventing and managing the global epidemic, 1998 - og sammendragene fra The Eight International Congress on Obesity i Paris 1998 (Int J Obes 1998; 22 (suppl 3)), ble gjennomgått.

- Referanselister til andre tilgjengelige rapporter ble gjennomgått.

- Personer som har forsket på vekt i den norske befolkning og forskere med interesse for vekt/helsespørsmål, ble kontaktet.
Søkene ble begrenset til studier av vektendring, vektøkning, vektreduksjon og vektfluktuasjon (weightcycling) på mennesker - og til voksne personer. Hovedvekten er lagt på observasjonsstudier med mange deltakere, lang oppfølgingstid og død som endepunkt. Søkene på sykdom og risikofaktorer som endepunkt, ble begrenset til de sykdommer/ risikofaktorer som er omtalt i WHO-rapporten fra 1998. Søkene ble avsluttet i desember 1999.

\section{VEKT OG TOTALDØDELIGHET}

Vår kunnskap om sammenhengen mellom KMI og sykelighet/dødelighet er i overveiende grad basert på observasjons- og "pasient-kontroll" studier, som ikke alene kan si noe sikkert om årsak. Det er vanskelig å vite om kroppsvekten er årsak til sykdommen eller om sykdommen forårsaker endret kroppsvekt, selv om man metodisk prøver å kontrollere for subklinisk sykdom i analysene. Det er ikke enighet om sammenhengen mellom KMI og død har form av U, J eller om dødeligheten øker lineært med økende KMI (Manson et al., 1987; Kushner, 1993; Solomon og Manson, 1997; Willett et al. 1999; Gaesser, 1999; SEF-rapport, 2000).

Man finner i store representative studier overdødelighet blant individer med KMI > 27 (SEF-rapport, 2000). Enkelte studier viser en lavere grense når man analyserer utvalgte grupper av ikke-røykere (Calle et al., 1999). Flere studier tyder på at samvariasjonen mellom KMI og totaldød svekkes ved justering for fysisk aktivitet - og enkelte hevder at manglende fysisk aktivitet er en like viktig prediktor for død som overvekt og fedme (Blair og Brodney, 1999, Gaesser 1999). Sammenhengen mellom KMI og totaldød ser ut til å være noe svakere for kvinner enn for menn - og den er svak eller ikke til stede blant de eldste (Waaler, 1984; Stevens et al., 1998a). De største materialene viser et relativt stort område med optimal KMI (inntil 9 KMI-enheter) der hverken en liten nedgang eller oppgang i vekt gir særlig store utslag på totaldødeligheten (Waaler, 1984, SEF-rapport, 2000). Sammenhengen mellom KMI og sykdomsspesifikk død varierer sterkt avhengig av hvilken sykdom man studerer (SEF-rapport, 2000).

Mange studier tyder på overdødelighet blant yngre individer ( $<30$ år) med KMI $<19$ og blant middelaldrende med $\mathrm{KMI}<21$. I noen studier forsvinner denne overdødeligheten etter eksklusjon av personer med subklinisk sykdom, og etter justering for røyking og andre relevante faktorer, mens denne overdødeligheten blant de tynneste fortsatt er til stede i flertallet av studiene (SEF-rapport, 2000).

\section{VEKTØKNING}

Ikke bare kroppsmasseindeks per se, men også vektøkning har i mange studier vist seg å være en selvstendig risikofaktor for sykdom og død. 


\section{Dodelighet}

Andres et al. (1993) har laget en oversikt over 11 ulike studier av vektendring og dødelighet. De fant gjennomgående lavest dødelighet blant dem med moderat vektøkning (2,5-4,4 KMI enheter) - også i forhold til dem med stabil vekt. Det var høyest dødelighet blant dem som hadde økt svært mye. Tabell 1 gir en kort oversikt over noen av studiene som analyserer vektendring og dødelighet - med antall individer og oppfølgingstid.

Lee og Paffenbarger (1992) fant at stabil vekt ( \pm èn $\mathrm{kg}$ ) var assosiert med lavest dødelighet. Vektøkning på $>5 \mathrm{~kg}$ ga økt relativ risiko (RR) for totaldød og død av kardiovaskulære sykdommer. I en delstudie med primært fokus på fysisk aktivitet fant man at menn med minst vektøkning siden college hadde høyere dødelighet enn dem med mest vektøkning (Paffenbarger et al., 1986). Dødeligheten sank med økende vektøkning og økende nåværende fysisk aktivitet.

Yaari og Goldbourt (1998) viste at vektøkning, både $2-4 \mathrm{~kg} \mathrm{og} \geq 5 \mathrm{~kg}$, samvarierte med redusert dødelighet (ikke statistisk signifikant etter justering for konfoundere). Personer med utgangs-KMI på 22-27 og stabil vekt eller vektøkning hadde lavest dødelighet.

Også i Honolulu Heart Study var en liten vektøkning (2,5-4,5 kg) assosiert med den laveste dødeligheten (Iribarren et al., 1995).

I Framingham-studien fant man at vektøkning samvarierte med økt dødelighet bare blant dem som var i øvre $1 / 3$ mht. vekt i utgangspunktet - og det gjaldt både totaldød og død av kardiovaskulære sykdommer (Higgins et al. 1993). De øvrige 2/3 hadde $\mathrm{RR}=0,78-0,86$ for totaldød sammenlignet med dem med stabil vekt.

Mikkelsen et al. (1998) registrerte i en dansk studie vekt og vektendring samtidig. Vektøkning til KMI > 28 var assosiert med høyere risiko for totaldød - uavhengig av initial vekt, mens vektøkning til lavere verdier ikke hadde sammenheng med økt risiko for død.

Blant ikke-røykende sykepleiere (Nurses' Health Study) ga vektøkning på under $10 \mathrm{~kg}$ ingen signifikant overdødelighet $\mathrm{i}$ forhold til dem med stabil vekt fra 18 års alder. Derimot ga vektøkning på 10-19 kg en økt risiko $(\mathrm{RR}=1,2)$, og vektøkning på $\geq 20 \mathrm{~kg}$ ga $\mathrm{RR}=$ 1,6 for total død. Kreftdød hadde signifikant økt RR først ved $\geq 20 \mathrm{~kg}$ (Manson et al., 1995).

Blant premenopausale kvinner i samme studie ga vektøkning på $\geq 20 \mathrm{~kg}$ fra 18 -årsalderen en svakt forhøyet risiko ( $R R=1,27, p=0,03$ for trend) for brystkreftdød sammenlignet med vektendring $\leq 2 \mathrm{~kg}$. Blant postmenopausale kvinner ga den samme vektøkningen $\mathrm{RR}=2,44$ for brystkreftdød. Blant kvinner som aldri hadde brukt hormonsubstitusjon (HRT) var assosiasjonen enda sterkere $(R R=3,80)$ (Huang et al., 1997).

\section{Sykelighet}

Kardiovaskulcere sykdommer og diabetes Willett et al. (1995) fant i Nurses' Health Study økt risiko for hjerte-kar sykdom ved $>5 \mathrm{~kg}$ vektøkning fra
18 års alder. Risikoen økte lineært fra $\mathrm{RR}=1,25$ for $5-7,9 \mathrm{~kg}$ til $\mathrm{RR}=2,65$ for $\geq 20 \mathrm{~kg}$. Det var ingen særlig økning i risiko for andre enn dem med utgangs $\mathrm{KMI} \geq 23$.

I samme studie fant man en økt risiko for isjemiske og alle slag, men ikke blødningsslag ved vektøkning > $11 \mathrm{~kg}$ fra 18 års alder (Rexrode et al., 1997). Relativ risiko for isjemisk slag etter justering for konfunderende variabler og vekt ved 18 års alder, var 1,69 for vektøkning på 11-19,9 kg sammenlignet med vektøkning/tap $<5 \mathrm{~kg}$.

Man fant i denne studien også at kvinner uten noen alvorlige sykdommer ved starten, hadde en økt risiko for diabetes type II ved vektøkning > $5 \mathrm{~kg}$ fra 18 års alder etter justering for konfunderende variabler og vekt ved 18 års alder. Sammenlignet med vektøkning/ tap $<5 \mathrm{~kg}$ var $\mathrm{RR}=1,79$ ved vektøkning $5-7,9 \mathrm{~kg}$ og $\mathrm{RR}=2,7$ ved vektøkning 8,0-10,9 kg (Colditz et al., 1995).

Vektøkning på > 11 kg i løpet av 10 år ga også statistisk signifikant økt risiko for å utvikle diabetes type II i NHANES-studien. Relativ risiko økte lineært med økende vektøkning (Ford et al., 1997). Det var ingen kjønns- eller aldersforskjell i relativ risiko for utvikling av NIDDM (non-insulin-dependent diabetes mellitus). En økning i vekt på $5 \mathrm{~kg}$ eller mer ga en tilskrivbar risiko for type II diabetes på $27 \%$.

\section{Risikofaktorer for kardiovaskulcere sykdommer og diabetes}

Field et al., (1999) fant i Nurses' Health Study II, blant vel 46000 kvinner som ikke hadde høyt blodtrykk ved studiestart, at selvrapportert ny hypertensjon økte med $20 \%(\mathrm{OR}=1,20)$ for hver $4,5 \mathrm{~kg}$ vektøkning kvinnene hadde $\mathrm{i}$ en 4 års periode.

I Framingham-studien var vektøkning assosiert med økning i mange av risikofaktorene som har sammenheng med kardiovaskulære sykdommer - f.eks blodtrykk (Higgins et al., 1993).

Det er også funnet at selvrapportert vektøkning mellom 25- og 45-64 års alder blant vel 13000 menn og kvinner, var positivt assosiert med tykkelsen av a.carotis veggen, et mål som representerer et steg $\mathrm{i}$ atherosklerose-prosessen (Stevens et al., 1998b).

\section{Kreft}

Vektøkning fra 18-årsalderen var ikke assosiert med brystkreft blant premenopausale kvinner etter 16 års oppfølging i Nurses' Health Study (Huang et al., 1997). Blant postmenopausale kvinner ga en vektøkning på $\geq 20 \mathrm{~kg}$ siden 18 -årsalderen en $\mathrm{RR}=1,4$ for brystkreft sammenlignet med en vektendring $\leq 2 \mathrm{~kg}$. Blant kvinner som aldri hadde brukt HRT var sammenhengen enda sterkere $(\mathrm{RR}=1,99)$, mens det ikke var noen sammenheng mellom vektøkning og brystkreft blant brukere og tidligere brukere av HRT postmenopausalt. Denne og andre studier (Ballard-Barbash et al., 1990; Le Marchand et al., 1988) tyder forøvrig på at det er vektøkning siden 18 års alder - ikke 
aktuell vekt, som er viktigst for utvikling av brystkreft etter menopausen. Mer enn $2 \mathrm{~kg}$ vektøkning siden 18 års alder forklarte $16 \%$ av alle postmenopausale krefttilfeller (tilskrivbar risiko i befolkningen), bruk av HRT 5\% - mens disse 2 faktorene sammen forklarte $34 \%$ av alle krefttilfellene (Huang et al., 1997).

I en svensk "pasient-kontroll" studie av vel 3300 kvinner med invasiv brystkreft $i$ alderen 50-74 år, viste man at de som hadde økt sin vekt med $30 \mathrm{~kg}$ eller mer siden 18-årsalderen og var minst 20 år postmenopausale, hadde en odds ratio for brystkreft på 2,04 sammenlignet med dem som hadde holdt vekten uendret (Magnussen et al., 1998). Sammenhengen gjaldt imidlertid bare de som aldri hadde brukt HRT.

\section{Osteoporose og brudd}

Menn og kvinner i Tromsø som hadde økt vekten mellom 1980 og 1987 hadde lavere risiko for lårhalsbrudd $(\mathrm{RR}=0,69$ for menn - aldersjustert pr. enhet KMI økning) og for alle lav-energibrudd i underekstremitetene ( $\mathrm{RR}=0,88$ for kvinner - aldersjustert pr. enhet KMI økning) (Joakimsen et al., 1998).

Meyer et al. (1998) fant i en studie av lårhalsbrudd blant 39000 middelaldrende personer fra 3 fylker i Norge (gjennomsnittlig 11,6 års oppfølging etter screening - 3 målepunkter for hver person) synkende frakturrate med økende vektøkning, også justert for vektfluktuasjon, men det var vide konfidensintervall. Det synes som det er gunstigere for menn enn kvinner å legge på seg. $2,1-5 \mathrm{~kg}$ vektøkning for menn ga $\mathrm{RR}=$ 0,48 (grensesignifikant) for lårhalsbrudd. For menn som gikk ned $i$ vekt vs. de som økte var $R R=2$, mens det ikke var noen slik sammenheng blant kvinner.

En annen norsk undersøkelse (29 802 spørreskjemasvar $-64 \%$ responsrate) av postmenopausale kvinner 50-80 år, viste at de som rapporterte vektøkning siden 25 års alder hadde redusert risiko for lårhals- og vertebrale frakturer (Gunnes et al., 1996).

Tabell 1. Vektendring og dødelighet. Forkortelser: $\mathrm{KMI}=$ kroppsmasseindeks $\left(\mathrm{kg} / \mathrm{m}^{2}\right), \mathrm{CVD}=$ kardiovaskulær sykdom, $\mathrm{CHD}=$ koronar hjertesykdom, $\mathrm{RR}=$ relativ risiko, $\mathrm{OR}=$ odds ratio, $\mathrm{HRT}=$ hormonsubstitusjon.

\begin{tabular}{|c|c|c|c|c|c|}
\hline Forfattere & Studie & Alder & $\begin{array}{l}\text { Antall } \\
\text { (ca.) }\end{array}$ & $\begin{array}{l}\text { Observa- } \\
\text { sjonstid, } \\
\text { antall år }\end{array}$ & Hovedkonklusjon \\
\hline $\begin{array}{l}\text { Mikkelsen } \\
\text { et al. } 1998\end{array}$ & & & 15100 & 10,5 & $\begin{array}{l}\text { Vektøkning til KMI } \geq 28 \text { ga økt relativ risiko for totaldød - uavhengig av } \\
\text { initial vekt, mens vektøkning til lavere verdier ikke ga signifikant økt risi- } \\
\text { ko for død. Vektnedgang hadde sammenheng med signifikant økt risiko } \\
\text { for død. Både vektøkning og vektnedgang til en bestemt KMI økte risikoen } \\
\text { for død mer enn hvis man var stabil på denne vekten. Unntak var stabil } \\
\text { vekt på } \geq 28 \text { som ga meget høy risiko, og KMI }<22 \text { som også hadde } \\
\text { høyere risiko enn vektøkning. }\end{array}$ \\
\hline $\begin{array}{l}\text { Singh et al. } \\
1998\end{array}$ & $\begin{array}{l}\text { Adventist } \\
\text { Mortality } \\
\text { Study }\end{array}$ & $30-74$ år & $\begin{array}{l}12600 \text { aldri- } \\
\text { røykere, } \\
\text { kvinner }\end{array}$ & i- & $\begin{array}{l}\text { I gruppen med stabil vekt og ingen respirasjonssykdom ved baseline, ga } \\
\text { vekttap økt dødelighet. }\end{array}$ \\
\hline $\begin{array}{l}\text { Lissner et al. } \\
1991\end{array}$ & $\begin{array}{l}\text { Framingham } \\
\text { Heart Study }\end{array}$ & $\begin{array}{l}49-82 \\
\text { år ved } \\
\text { baseline }\end{array}$ & 1700 & 14 & $\begin{array}{l}\text { De med størst vektfluktuasjon hadde } \mathrm{RR}=1,3-2,0 \text { for totaldød og for } \\
\text { CHD-død sammenlignet med dem med minst vektfluktuasjon. }\end{array}$ \\
\hline
\end{tabular}

Higgins $\quad$ Framingham $\quad 35-54 \quad 2500 \quad 20 \quad$ Vektnedgang økte risikoen for totaldød, CVD- og CHD-død for menn et al. 1993 Offspring år ved $(\mathrm{RR}=1,3-1,6)$, og totaldød for kvinner $(\mathrm{RR}=1,4)$, etter eksklusjon av Study baseline $\quad$ døde de første 4 årene. Referansekategori var de med stabil vekt. Vektøkning økte dødeligheten bare blant dem som var i øvre 1/3 mht. vekt i utgangspunktet - og det gjaldt både totaldød, CVD-død og CHD-død. De øvrige $2 / 3$ med vektøkning hadde $\mathrm{RR}=0,78-0,86$ for totaldød sammenlignet med dem med stabil vekt.

\begin{tabular}{|c|c|c|c|c|c|}
\hline & & & & & \\
\hline $\begin{array}{l}\text { Lee et al. } \\
1992\end{array}$ & $\begin{array}{l}\text { Harvard } \\
\text { University } \\
\text { Alumni Study }\end{array}$ & 58 år & 11700 & 12 & $\begin{array}{l}\text { Stabil vekt }( \pm 1 \mathrm{~kg}) \text { ga lavest dødelighet. Med unntak av vektøkning på } 1 \text { - } \\
5 \mathrm{~kg} \text {, ga vektøkning og vektnedgang statistisk signifikant økt RR for } \\
\text { totaldød og CVD-død. }\end{array}$ \\
\hline $\begin{array}{l}\text { Paffenbarger } \\
\text { et al. } 1986\end{array}$ & & 35-74 år & 17000 & $12-16$ & $\begin{array}{l}\text { En delstudie som primært analyserte fysisk aktivitet, fant at menn med } \\
\text { minst vektøkning siden college hadde høyere dødelighet enn dem med } \\
\text { mest vektøkning. Dødeligheten sank med økende vektøkning og økende } \\
\text { nåværende fysisk aktivitet. }\end{array}$ \\
\hline $\begin{array}{l}\text { Manson } \\
\text { et al. } 1995\end{array}$ & $\begin{array}{l}\text { Nurses' Health } \\
\text { Study }\end{array}$ & $30-55$ år & $\begin{array}{l}115200 \\
\text { kvinner }\end{array}$ & 16 & $\begin{array}{l}\text { Blant ikke-røykere ga vektreduksjon og vektøkning på under } 10 \mathrm{~kg} \text { ingen } \\
\text { signifikant over/underdødelighet i forhold til dem med stabil vekt fra } 18 \\
\text { års alder. }\end{array}$ \\
\hline $\begin{array}{l}\text { Huang et al. } \\
1997\end{array}$ & & & & 16 & $\begin{array}{l}\text { Premenopausalt: Vektøkning på } \geq 20 \mathrm{~kg} \text { siden } 18 \text {-årsalderen ga svakt } \\
\text { forhøyet risiko }(\mathrm{RR}=1,27, \mathrm{p}=0,03 \text { for trend) for brystkreftdød } \\
\text { sammenlignet med en vektendring } \leq 2 \mathrm{~kg} \text {. } \\
\text { Postmenopausalt: Vektøkning på } \geq 20 \mathrm{~kg} \text { siden } 18 \text {-årsalderen ga } \mathrm{RR}= \\
2,44 \text { for brystkreftdød. Blant kvinner som aldri hadde brukt HRT var } \\
\text { sammenhengen enda sterkere }(\mathrm{RR}=3,80) \text {. }\end{array}$ \\
\hline $\begin{array}{l}\text { Yaari et al. } \\
1998\end{array}$ & & $40-65$ år & $\begin{array}{l}9200 \\
\text { menn }\end{array}$ & 18 & $\begin{array}{l}\text { De som frivillig reduserte vekten med } 5 \mathrm{~kg} \text { eller mer hadde statistisk } \\
\text { signifikant } ø k t \text { risiko for totaldød }(\mathrm{RR}=1,36) \text {, for } \mathrm{CVD} \text {-død }(\mathrm{RR}=1,33) \text {, } \\
\text { for } \mathrm{CHD} d ø \mathrm{~d}(\mathrm{RR}=1,55) \text {, men ikke for cancerdød. }\end{array}$ \\
\hline
\end{tabular}


Tabell 1 (Fortsatt).

\begin{tabular}{|c|c|c|c|c|c|}
\hline Forfattere & Studie & Alder & $\begin{array}{l}\text { Antall } \\
\text { (ca.) }\end{array}$ & $\begin{array}{l}\text { Observa- } \\
\text { sjonstid }\end{array}$ & Hovedkonklusjon \\
\hline $\begin{array}{l}\text { Losonczy } \\
\text { et al., } 1995\end{array}$ & $\begin{array}{l}\text { Established Popu- } \\
\text { lations for Epide- } \\
\text { miologic Studies } \\
\text { of the Elderly }\end{array}$ & $\begin{array}{l}70 \text { år } \\
\text { og } \\
\text { eldre }\end{array}$ & 6300 & 20 år & $\begin{array}{l}\text { De som gikk ned } \mathrm{i} \text { vekt med } \geq 10 \% \text { hadde } ø \mathrm{kt} \text { dødelighet } \mathrm{i} \text { forhold til dem } \\
\text { med stabil vekt }(\mathrm{RR}=1,69 \text { for menn og } \mathrm{RR}=1,62 \text { for kvinner). Hvis man } \\
\text { ekskluderte disse, og justerte for helsetilstand, var det ingen overdødelighet } \\
\text { i resten av materialet. }\end{array}$ \\
\hline $\begin{array}{l}\text { Diehr et al. } \\
1998\end{array}$ & $\begin{array}{l}\text { The Cardio- } \\
\text { vascular } \\
\text { Health Study }\end{array}$ & $\begin{array}{l}65-100 \\
\text { år }\end{array}$ & $\begin{array}{l}4300 \\
\text { ikke- } \\
\text { røykere }\end{array}$ & 5 & $\begin{array}{l}\text { Personer som hadde tapt } 10 \% \text { eller mer av kroppsvekten siden } 50 \text { års alder } \\
\text { hadde dobbelt så høy dødelighet som dem med mindre vekttap, dem med } \\
\text { stabil vekt eller dem med vektøkning. De som reduserte vekten frivillig vha. } \\
\text { diett og fysisk aktivitet i løpet av siste år, hadde samme dødelighet som dem } \\
\text { som hadde stabil vekt, og dem som økte vekten (bare menn). }\end{array}$ \\
\hline $\begin{array}{l}\text { Andres } \\
\text { et al. } 1993\end{array}$ & $\begin{array}{l}\text { Oversikt over } \\
13 \text { rapporter } \\
\text { fra } 11 \text { studier }\end{array}$ & & & $\begin{array}{l}\text { Minst } 4 \text { års } \\
\text { oppfølging } \\
\text { på vekt og } \\
8 \text { år på død }\end{array}$ & $\begin{array}{l}\text { Lavest dødelighet blant dem med moderat vektøkning }(2,5-4,4 \mathrm{KMI} \text { enheter), } \\
\text { også i forhold til dem med stabil vekt. } \\
\text { Høyest dødelighet blant dem som hadde tapt vekt - både mild og moderat - } \\
\text { og blant dem som hadde økt svært mye. }\end{array}$ \\
\hline $\begin{array}{l}\text { Lee et al. } \\
1996\end{array}$ & $\begin{array}{l}\text { Gjennomgang } \\
\text { av } 17 \text { studier } \\
\text { på vekttap } \\
\text { og død }\end{array}$ & & & & $\begin{array}{l}2 \text { studier viste at vekttap ga lengre levetid, mens èn studie hevdet at de fant } \\
\text { dette - uten å vise data. } 2 \text { studier fant gunstig effekt av moderat vekttap i } \\
\text { noen undergrupper, og positiv effekt av moderat vektøkning i andre. } 4 \text { studier } \\
\text { viste at vedlikehold av vekten ga lavest dødelighet. } 2 \text { studier viste at moderat } \\
\text { vektøkning var det gunstigste. } \\
3 \text { studier konkluderte med at vekttap økte dødeligheten, } 1 \text { studie fant redusert } \\
\text { dødelighet med minkende vekttap, } 2 \text { studier viste ingen sammenheng. }\end{array}$ \\
\hline $\begin{array}{l}\text { Iribarren } \\
\text { et al. } 1995\end{array}$ & $\begin{array}{l}\text { Honolulu } \\
\text { Heart Study }\end{array}$ & 45-68 år & $\begin{array}{l}6500 \\
\text { menn }\end{array}$ & 14,5 & $\begin{array}{l}\text { Vekttap på } 2,6 \mathrm{~kg} \text { eller mer var assosiert med } ø k t \text { risiko for totaldød og død } \\
\text { av ikke-CVD/ikke-cancer sykdommer - etter justering for vekt ved baseline, } \\
\text { konfunderende variable og ekslusjon av døde de første } 5 \text { årene. } \\
\text { De med størst vektfluktuasjon hadde } ø \text { kt risiko for totaldød }(\mathrm{RR}=1,25) \text {, } \\
\text { CVD død }(\mathrm{RR}=1,41) \text { og ikke-cancer/ikke-CVD død }(\mathrm{RR}=1,53) . \text { Denne } \\
\text { sammenhengen var imidlertid ikke til stede blant friske, ikke-røykende menn. }\end{array}$ \\
\hline $\begin{array}{l}\text { Pamuk et al. } \\
1992\end{array}$ & NHANES I & 45-74 år & 5000 & 10 & $\begin{array}{l}\text { Kontroll for alder, etnisitet, røyking, paritet, eksisterende sykdom og mak- } \\
\text { simum KMI, viste at risikoen for død økte med økende vekttap }>5 \% \text { hvis de } \\
\text { hadde maksimal livs-KMI } 26-<29 \text {. Relativ risiko var doblet for personer } \\
\text { som gikk ned } 15 \% \text { sammenlignet med dem som gikk ned }<5 \% \text {. Den samme } \\
\text { assosiasjonen var også til stede blant kvinner med KMI }>29 \text {, mens de tyngste } \\
\text { mennene som reduserte } 5-<15 \% \text { i vekt, reduserte sin risiko. }\end{array}$ \\
\hline
\end{tabular}

Pamuk et al. $\quad$ 45-74 år 5000

1993

Ekskluderte alle som døde inntil 8 år etter baseline - og stratifiserte på røyking. Samme resultat som over for død av kardiovaskulær sykdom, men svakere assosiasjon for andre dødsårsaker. Blant ikke-røykere var RR 2,3-3,6 for kardiovaskulær død hvis de hadde maksimal livs-KMI 26 - $<29$ og gikk ned $>5 \%$ i vekt sammenlignet med dem som gikk ned $<5 \%$. Større vekttap ga også økt risiko for død av andre årsaker.

\begin{tabular}{lll}
\hline $\begin{array}{l}\text { Williamson } \\
\text { et al. } 1999\end{array}$ & $40-64$ år & $49300 \quad 12-13$ \\
& hvite menn \\
& KMI $\geq 27$
\end{tabular}

Tilsiktet vektreduksjon på 9,1 kg eller mer ga ingen sammenheng mellom og totaldødelighet eller CVD død blant de vel 36000 som ikke rapporterte sykdom ved baseline. Økning på 48\% i dødeligheten av diabetes-assosierte dødsfall. Heller ingen sammenheng for dem med sykdommer ved baseline. De med tilsiktet vektreduksjon på mindre enn $9,1 \mathrm{~kg}$ hadde $22 \%$ reduksjon $\mathrm{i}$ diabetes-assosierte dødsfall.

\begin{tabular}{|c|c|c|c|c|c|}
\hline $\begin{array}{l}\text { French et al. } \\
1999\end{array}$ & $\begin{array}{l}\text { Iowa Women's } \\
\text { Health Study }\end{array}$ & $\begin{array}{l}\text { Siden } \\
18 \text { års } \\
\text { alder }\end{array}$ & $\begin{array}{l}26000 \\
\text { kvinner }\end{array}$ & & $\begin{array}{l}\text { Ingen sammenheng mellom totaldød og det å ha minst en episode med } \\
\text { frivillig vektreduksjon i noen gruppe av initial KMI. Det var heller ingen } \\
\text { sammenheng med CVD-død. }\end{array}$ \\
\hline $\begin{array}{l}\text { Williamson } \\
\text { et al. } 1995\end{array}$ & & 40-64 år & $\begin{array}{l}40000 \text { ikke- } \\
\text { røykende } \\
\text { kvinner } \\
\text { KMI } \geq 27\end{array}$ & 12 & $\begin{array}{l}20 \% \text { reduksjon i dødeligheten blant kvinner som hadde vektrelaterte syk- } \\
\text { dommer på forhånd - f.eks. diabetes og høyt blodtrykk, og som frivillig } \\
\text { reduserte vekten. Det som bidro var } 40-50 \% \text { reduksjon i cancer-død og } 30 \text { - } \\
40 \% \text { reduksjon i diabetes-relatert død. Ingen reduksjon i dødelighet blant } \\
\text { friske overvektige personer som gikk ned i vekt. }\end{array}$ \\
\hline $\begin{array}{l}\text { Singh et al. } \\
1993\end{array}$ & $\begin{array}{l}\text { Randomisert } \\
\text { intervensjons- } \\
\text { studie }\end{array}$ & & $\begin{array}{l}406 \\
\text { personer } \\
\text { med akutt } \\
\text { hjerte- } \\
\text { infarkt }\end{array}$ & 12 uker & $\begin{array}{l}\text { Randomisert studie }-204 \mathrm{i} \text { intervensjonsgruppen, } 202 \mathrm{i} \text { kontrollgruppen. Det } \\
\text { var signifikant redusert sykelighet } \mathrm{i} \text { intervensjonsgruppen som fikk } \\
\text { antioksidantrik kost som tilbehør til et forsiktig kosthold. Nye infarkt: } 37 \mathrm{i} \\
\text { intervensjonsgruppen vs. } 58 \mathrm{i} \text { kontrollgruppen }(\mathrm{p}<0,01) \text {. De } 108 \text { personene } \mathrm{i} \\
\text { intervensjonsgruppen som holdt seg strengt til dietten hadde redusert } \\
\text { hjertedødelighet ( } 6 \mathrm{i} \text { intervensjonsgruppen og } 28 \mathrm{i} \text { kontrollgruppen, } \mathrm{p}< \\
0,001) \text {. Reduksjonen i dødelighet var størst } \mathrm{i} \text { gruppen som reduserte vekten } \\
\text { med ca. } 10 \% \text {. }\end{array}$ \\
\hline $\begin{array}{l}\text { Blair et al. } \\
1993\end{array}$ & $\begin{array}{l}\text { Multiple Risk } \\
\text { Factor Inter- } \\
\text { vention Trial }\end{array}$ & $35-57$ & $\begin{array}{l}10500 \\
\text { menn med } \\
\text { høy risiko } \\
\text { for CHD }\end{array}$ & 3,8 & $\begin{array}{l}\text { Multisenterstudie av de } 10-15 \% \text { med høyest risiko for koronar hjertesykdom. } \\
\text { Deltakerne ble fulgt opp hvert år i 6-7 år. Personer i høyeste kvartil av } \\
\text { vektvariasjon (intrapersonal standard deviation of weight (ISD) hadde RR = } \\
1,64 \text { for totaldød i forhold til dem i laveste. Det var samme mønster for } \\
\text { kardiovaskulær død. Denne assosiasjonen var imidlertid ikke til stede blant } \\
\text { mennene med høyest KMI. }\end{array}$ \\
\hline $\begin{array}{l}\text { Hamm et al. } \\
1989\end{array}$ & $\begin{array}{l}\text { Western } \\
\text { Electric } \\
\text { Study }\end{array}$ & $40-55$ år & 2000 & 25 & $\begin{array}{l}\mathrm{RR}=1,8 \text { for død av CVD blant menn som hadde minst } 10 \% \text { vekt } \varnothing \text { kning og } \\
\text { minst } 10 \% \text { vekttap - sammenlignet med dem med relativ stabil vekt }- \text { etter } \\
\text { justering for en rekke risikofaktorer inkludert KMI. }\end{array}$ \\
\hline $\begin{array}{l}\text { Pietrobelli } \\
\text { et al (1998) }\end{array}$ & $\begin{array}{l}\text { Reanalyse: } \\
\text { Tecumseh Heart } \\
\text { Study og Framing } \\
\text { ham Heart Study }\end{array}$ & & 1890 & & $\begin{array}{l}\text { Tap av kroppsfett førte til lavere totaldødelighet }(\mathrm{OR}=0,97 \mathrm{og} \mathrm{OR}=0,83 \mathrm{i} \\
\text { de } 2 \text { studiene), mens vekttap førte til økt dødelighet }(\mathrm{OR}=1,02 \mathrm{og} \\
\mathrm{OR}=1,06) \text { (målt ved hhv. hudfoldtykkelse og vekttap i kg). }\end{array}$ \\
\hline
\end{tabular}


Prosent vektøkning siden 25 års alder hadde også invers sammenheng med lårhalsbrudd $i$ en studie av vel 8000 ikke-fargede kvinner ( $\geq 65$ år, fulgt i gjennomsnittlig 5,2 år) (Ensrud et al., 1997a). De med minst prosentvis vektøkning hadde signifikant større risiko (30\%) enn dem med størst økning. Den signifikant økte risiko hos dem med lavest vektøkning ble forsterket etter justering for høyde ved 25 års alder, røyking, fysisk aktivitet, helsestatus, bruk av østrogen, og bruk av diuretica. Relativ risiko for laveste vektøkning (5\%) vs. den høyeste var 2,7. Det var størst endring i RR mellom kvartil 1 og 2 -dvs. mellom en KMI-økning på $5 \%$ og $16,4 \%$. Etter justering for femoral bentetthet var det ikke lenger særlig forskjell mellom dem som hadde stor eller liten vektøkning. Dette tilsier at risikoen for lårhalsbrudd ved mang lende vektøkning for en stor del går gjennom tap av benmasse.

Menn som økte vekten $\geq 10 \%$ fra 50 års alder hadde en signifikant redusert risiko for lårhalsbrudd $(\mathrm{RR}=0,38)-$ justert for en rekke konfunderende variable - bl.a. alder, røyking, KMI ved baseline og antall medisinske tilstander (ca. 8 års oppfølging av nær 3000 menn - 67-104 år ved 2. screening) (Langlois et al., 1998).

En analyse av kvinnene i samme studie $(\mathrm{n}=3$ 683) ga samme funn som for menn (Langlois et al., 1996). De med vektøkning på $\geq 10 \%$ hadde en ikke-signifikant risikoreduksjon ( $\mathrm{RR}=0,7$; KI 0,4-1,06) sammenlignet med dem med $<5 \%$ vektendring.

\section{Psykososiale konsekvenser}

Det er vanskelig å finne undersøkelser som beskriver endringer i psykososiale variable etter vektøkning. Et utvalg av personer fra helseundersøkelsen Finnmark III (1987/88), dvs. innbyggerne i 5 kystkommuner (2069 år), ble fulgt opp i 1990 og 1993 med de samme målinger og spørsmål (første periode 1937 personer, andre periode 2065 personer). Hverken for menn eller kvinner var det noen sammenheng mellom vektendring og etterfølgende selvvurdert helse, justert for alder. Heller ikke generell tilfredshet med livet samvarierte statistisk med endring i BMI (upubliserte data, AJ Søgaard). En mindre longitudinell studie kom til samme konklusjon etter å ha fulgt 400 menn og kvinner over et år (Klesges et al., 1992). Det var ingen endring i psykososial helse - målt med flere ulike psykologiske testbatterier, som resultat av endring $i$ vekt - verken for menn eller kvinner. Derimot fant Jamison et al. (1990) at en gruppe pasienter $(n=155)$ med kroniske smerter som gikk opp mer enn 7,5 kg i vekt, hadde økt følelsesmessig ubehag sammenlignet med en gruppe smertepasienter $(n=341)$ som hadde stabil vekt.

Sammenfattet kan vi si at langsom moderat vektøkning gjennom livet inntil KMI 27 ikke ser ut til å gi særlige negative utfall mht. dødelighet. Vektøkning $\geq$ $20 \mathrm{~kg}$ fra 18 års alder er trolig negativt - det samme er vektøkning ut fra en høy utgangsvekt. Enkelte studier tyder på økt risiko for kardiovaskulær sykdom - og spesielt diabetes ved noe mindre vektøkning. Man har også funnet økte verdier på en rekke risikofaktorer for disse sykdommene ved moderat vektøkning. Flere studier finner økt risiko for brystkreft postmenopausalt ved kraftig vektøkning, mens risikoen for lårhalsbrudd reduseres etter vektøkning.

\section{VEKTREDUKSJON}

Med bakgrunn i den oppmerksomhet som eksisterer rundt overvekt og slanking - både fra helsepersonell, media og markedsførere av ulike slankeprodukter, skulle man forvente at det var en klar og overbevisende kunnskap når det gjelder risikoene ved overvekt - og fordelene ved slanking. Denne oversikten har så langt vist at det ikke finnes entydig kunnskap når det gjelder helsekonsekvensene av moderat overvekt og moderat vektøkning. Hva viser så litteraturen når det gjelder vektreduksjon og slanking?

Innledningsvis kan det være interessant å se hvilke utslag "slankhetsidealet" og det sosiale presset som eksisterer mht. å gå ned i vekt, kan ha på unge voksne. I Finnmark ( $\mathrm{n}=12172,20-69$ år) oppga $60 \%$ av kvinnene at de ønsket å slanke seg i 1987/88, mens prosentandelen blant mennene var 40 (BK Jacobsen, Institutt for samfunnsmedisin, UiTø, upubliserte data). Det var imidlertid ikke bare dem som veide mest som ønsket å gå ned i vekt: Av kvinner under 30 år med KMI 20-24,9 ønsket 48\% å slanke seg, mens tallet var $96 \%$ for dem i tilsvarende aldersgruppe med KMI 25-29,9. Blant menn under 35 år ønsket over $60 \%$ av dem med KMI 25-29,9 å slanke seg. WHO opererer med en grense på KMI $\geq 30$ for fedme (WHO-report, 1998, s. 9). Norske mannlige landslagsutøvere har i gjennomsnitt KMI rett under 25 (Jorunn SundgotBorgen, personlig meddelelse).

I det følgende vil vi referere studier som har undersøkt helsekonsekvensene av vektreduksjon. Hovedvekten er lagt på langtidsstudier med mange personer - med sykelighet og dødelighet som endepunkt.

\section{Dodelighet}

Andres et al. (1993) viste i sin oversikt over 11 studier at det var høyere dødelighet blant dem som hadde tapt vekt - både mild og moderat, enn dem med stabil vekt (tabell 1). De brukte studier som på ulike måter hadde forsøkt å eliminere effekten av ufrivillig vekttap, bl.a. ved å ekskludere dem med vekttap umiddelbart før/etter starten av oppfølgingen, de som døde de første årene - og/eller ved eksklusjon av alle med kjent sykdom ved studiestart. Det er imidlertid komplisert å skille de to typer av vekttap, hvilket ofte gjør det vanskelig å konkludere.

Williamson og Pamuk (1993) gjennomgikk 6 studier publisert mellom 1951 og 1990 som oppga positiv effekt av vektreduksjon på død. De fant imidlertid at 2 av disse ikke godtgjorde en slik samvarisajon i sine data, mens 2 andre viste $ø k t$ dødelighet i noen under- 
grupper og redusert dødelighet $\mathrm{i}$ andre. De 2 siste studiene hadde så store metodiske svakheter at forfatterne konkluderte med at man på basis av disse 6 studiene ikke kunne trekke den konklusjonen at vektreduksjon fører til redusert dødelighet. Bare èn av de 6 studiene hadde forøvrig skilt mellom frivillig og ufrivillig vektreduksjon, men i denne fant man samme effekt av vektreduksjon uavhengig av intensjon.

En gjennomgang av 17 studier av vekttap og dødelighet konkluderer med at begrensningene ved eksisterende studier tilsier at man ikke uten videre kan anbefale overvektige å redusere vekten (Lee og Paffenbarger, 1996). Bare 2 av de 17 studiene viste en positiv assosiasjon mellom vekttap og forlenget levetid, mens èn studie hevdet at de fant dette - uten å vise data. Forfatterne konkluderer med at det beste vil være å sette inn ressurser for å få flest mulig til å holde en stabil vekt fra barne- og ungdomsårene inn i voksen alder.

På basis av egne og andres studier, konkluderer også Diehr et al. (1998) med at vekttap ser ut til å være assosiert med høyere dødelighet, men legger til at det er vanskelig helt å skille ut dem med ufrivillig vekttap.

En studie som prøvde å skille frivillig og ufrivillig vekttap, viste statistisk samvariasjon mellom frivillig vektreduksjon på $5 \mathrm{~kg}$ eller mer - og økt total dødelighet $(\mathrm{RR}=1,36)$, økt dødelighet av kardiovaskulære sykdommer $(\mathrm{RR}=1,33)$ og koronar hjertesykdom $(\mathrm{RR}$ $=1,55)$, men ikke av kreft (Yaari og Goldbourt, 1998). Resultatene endret seg lite etter eksklusjon av døde de første 5 årene. Justering for risikofaktorer for koronarsykdom og morbiditet ved slutten av studien reduserte RR med ca. 1/3, mens tilleggsjustering for disse variablene ved starten av studien reduserte RR ytterligere. Det var ingen statistisk signifikant forskjell på dødelighet mellom dem som rapporterte at de gikk inn for å redusere vekt gjennom kostregulering, og dem som gikk ned i vekt uten å ha dette som intensjon. De som prøvde å slanke seg hadde gjennomgående litt høyere dødelighet enn de øvrige - enten de gikk ned eller opp i vekt (Yaari og Goldbourt, 1998).

I en studie av vektreduksjon fra 50 til 70 års alder, fant man at de som gikk ned i vekt med $\geq 10 \%$ i denne perioden hadde økt dødelighet $\mathrm{i}$ forhold til dem med stabil vekt $(\mathrm{RR}=1,69$ for menn og $\mathrm{RR}=1,62$ for kvinner, Losonczy et al., 1995). Hvis man ekskluderte disse som gikk så mye ned i vekt, og justerte for helsetilstand, var det ingen overdødelighet i resten av materialet. Det er viktig å være klar over at frafallet underveis, bl.a. pga død, vil kunne påvirke konklusjonene.

Vekttap på 2,6 kg eller mer i Honolulu Heart Study var assosiert med økt risiko for totaldød - etter justering for vekt ved baseline, konfunderende variable og eksklusjon av døde de første 5 årene (Iribarren et al., 1995).

En 10 års oppfølging av NHANES I av personer med utgangsvekt på KMI 26-28,9 som overlevde i minst 5 år, viste at de som tapte vekt $>5 \%$, hadde signifikant $ø$ kt risiko for totaldød. Det samme hadde de kvinner som tapte $5 \%$ eller mer i vekt fra utgangsvekt $\geq 29$, mens de aller tyngste mennene hadde redusert risiko etter vektreduksjon på $\geq 5 \%$ (Pamuk et al., 1992).

I en reanalyse av det samme materialet (Pamuk et al. 1993), med eksklusjon av dem som døde de første 5-8 årene etter baseline og stratifisering på røyking, fant forfatterne ingen vesentlig endring i assosiasjonen mellom KMI og død av kardiovaskulær sykdom. Ikkerøykere som hadde en maksimal KMI gjennom livet på 26-28,9 og reduserte vekten med $>5 \%$ hadde RR mellom 2,3-3,6 for å dø av kardiovaskulær sykdom. Referansekategori var vekttap $<5 \%$. Større vekttap ga også økt risiko for død av andre årsaker.

I Framingham-studien med 20 års oppfølging og eksklusjon av døde de første 4 årene, viste man at vektnedgang økte risikoen for totaldød, død av kardiovaskulær sykdom og død av koronar hjertesykdom for menn $(\mathrm{RR}=1,3-1,6)$, og totaldød for kvinner $(\mathrm{RR}=$ 1,4) (Higgins et al. 1993).

Mikkelsen et al. (1998) viste at all vektnedgang var forbundet med signifikant økt risiko for død i forhold til dem med stabil vekt. Unntaket var stabil vekt på $\mathrm{KMI} \geq 28$ som ga høyere risiko.

Blant ikke-røykende sykepleiere ga vektreduksjon på under $10 \mathrm{~kg}$ ingen signifikant overdødelighet i forhold til dem med stabil vekt fra 18 års alder (Manson et al., 1995).

I en studie av overvektige menn $(\mathrm{KMI} \geq 27)$ fant man ingen assosiasjon mellom tilsiktet/ønsket vektreduksjon og total dødelighet blant dem som ikke rapporterte noen sykdom ved starten av studien (Williamson et al., 1999). Analysene var justert for alder, initial KMI, røyking, alkoholkonsum, utdanning, fysisk aktivitet, tidligere helsestatus og somatiske symptomer. Det var heller ingen samvariasjon mellom vektreduksjon og kardiovaskulære sykdommer eller kreftdødelighet blant dem som reduserte vekten med $\geq$ $9,1 \mathrm{~kg}$ i forhold til dem uten vektendring, mens de fant en økning på $48 \%$ i diabetes-assosierte dødsfall. På den annen side fant man en $22 \%$ reduksjon i diabetesassosierte dødsfall blant menn som reduserte vekten med $<9,1 \mathrm{~kg}$.

Blant dem som hadde ulike sykdomsdiagnoser ved baseline og reduserte vekten med $\geq 9,1 \mathrm{~kg}$, var det heller ingen assosiasjon mellom vektreduksjon og total dødelighet eller død av kardiovaskulære sykdommer.

Noen meget få studier har vist en reduksjon i dødeligheten etter vektreduksjon i spesielle undergrupper med spesielt høy risiko eller med etablert sykdom. Williamson et al. (1995) fant 20\% reduksjon i dødeligheten i en 12-årig prospektiv studie av ikke-røykende overvektige kvinner (KMI $\geq 27$ ) som hadde vektrelaterte sykdommer på forhånd (diabetes og høyt blodtrykk), og som frivillig reduserte vekten. Reduksjonen i dødelighet var uavhengig av hvor mye de gikk ned i vekt. Det som bidro til denne reduksjonen var for det meste en $40-50 \%$ reduksjon i kreft-død og 30-40\% 
reduksjon i diabetes-relatert død. Derimot var det ingen reduksjon i dødelighet blant friske overvektige personer som gikk ned i vekt.

I en indisk 12-ukers randomisert studie av 406 pasienter med akutt hjerteinfarkt var det signifikant redusert sykelighet og dødelighet $\mathrm{i}$ intervensjonsgruppen som fikk antioksidantrik kost i tillegg til lavt inntak av mettet fett, høyt inntak av fiber og økt fysisk aktivitet. Reduksjonen i dødelighet var størst i den undergruppen $\mathrm{i}$ intervensjongruppen som reduserte vekten med $10 \%$ (Singh et al., 1993).

Lean et al. (1990) fant gjennom en retrospektiv studie av journalene til 233 døde diabetespasienter, som overlevde minst ett år etter at diagnosen var stillet, en positiv assosiasjon mellom vektreduksjon og økt levetid. Ved hjelp av lineær, multippel regresjon der overlevelse var avhengig - og vektendring uavhengig variabel, fant man at hver $\mathrm{kg}$ vekttap for gjennomsnittspasienten tilsvarte 3-4 måneder lengre levetid. Det er uklart hva man har brukt som sammenligningsgruppe. Williamson og Pamuk (1993) fastslår imidlertid etter en kritisk gjennomgang av analysene, at det bare dreier seg om 0,015 måneder lengre levetid for hvert $\mathrm{kg}$ vekttap.

Williamson (1998) konkluderer, etter gjennomgang av 6 studier av assosiasjonen mellom vektreduksjon og dødelighet blant diabetespasienter, at de metodiske svakhetene ved alle studiene er store og resultatene motstridende. Noen konklusjon mht. konsekvensene av vektreduksjon for dødeligheten blant disse pasientene kan, i følge Williamson, foreløpig ikke trekkes.

\section{Sykelighet}

\section{Kardiovaskulcere sykdommer og diabetes}

Willett et al. (1995) fant i Nurses' Health Study verken økt eller redusert risiko for hjerte-karsykdommer ved vekttap, mens vekttap på $>5 \mathrm{~kg}$ ga $50 \%$ redusert risiko for diabetes type II (Colditz et al., 1995).

I Framingham-studien bidro vekttap til forbedringer i blodtrykk og kolesterolnivå, men de som hadde vekttap hadde lavere grad av røykeslutt, og hadde økt risiko for kardiovaskulære sykdommer, diabetes og andre sykdommer (Higgins et al., 1993).

Noe av det samme ble funnet $\mathrm{i}$ den før nevnte israelske studien (Yaari og Goldbourt, 1998), hvor man prøvde å skille mellom frivillig og ufrivillig vektreduksjon. Forfatterne fant at det å være på slankediett og redusere vekten med $\geq 5 \mathrm{~kg}$ i løpet av 5 år, medførte økt risiko for koronar hjertesykdom og diabetes type II, men redusert nivå av total serumkolesterol.

Vekttap var assosiert med en ikke-sigifikant reduksjon i risikoen for utvikling av diabetes type II i NHANES-studien (Ford et al., 1997).

\section{Risikofaktorer for kardiovaskulare sykdommer og diabetes}

I en av ytterst få intervensjonsstudier med langtidsoppfølging, deltok 41 svensker med nylig oppdaget diabe- tes type II og 181 personer med redusert glukosetoleranse (IGT) i en intervensjon over 6 år med fokus på diett og fysisk aktivitet (Eriksson og Lindgärde, 1991). Det var 2 kontrollgrupper - den ene besto av personer med redusert glukoseintoleranse som ikke fikk ekstra råd, den andre utgjorde friske personer. Det var statistisk signifikant bedring i fysisk aktivitet og reduksjon $\mathrm{i}$ kroppsvekt i de to intervensjonsgruppene i forhold til kontrollgruppene. I den ene intervensjonsgruppen hadde over $50 \%$ av personene med redusert glukosetoleranse normale verdier, og i den andre var over $50 \%$ av diabetespasientene i remisjon. Blant dem med redusert glukosetoleranse i intervensjonsgruppen var det 10,6\% insidens (akkumulert) av diabetes, mens det var 28,6\% i den ikke-randomiserte kontrollgruppen. Man fant også bedring i blodtrykk, lipidnivå og hyperinsulinemi $\mathrm{i}$ intervensjonsgruppene. Bedringene i glukosetoleransen var korrelert med vektreduksjon $(\mathrm{r}=0,19 ; \mathrm{p}<$ $0,02)$ og bedret fysisk form $(r=0,22 ; p<0,02)$. Det er likevel vanskelig å si hvilken betydning vektreduksjonen hadde for resultatet, $\mathrm{i}$ forhold til de andre elementene i denne studien.

Vektreduksjon hos pasienter med diabetes type II fører ofte til en gunstig effekt på metabolske parametre, men alle pasienter med type II diabetes responderer ikke like gunstig på vektreduksjon. Trolig er reduksjon av abdominalt fett viktigere enn vektreduksjon per se. I motsetning til andre sykdommer kan det se ut som det er fedme utviklet i voksen alder, ikke ungdommen, som er avgjørende for utvikling av diabetes type II (Must et al., 1992).

Mange studier har vist at moderat vektreduksjon (vekttap på opp til 10\%) kan føre til redusert blodtrykk, forbedret glukosekontroll, redusert kolesterolnivå og forbedret dyslipidemi (WHO-report, 1998, s. 74; Goldstein, 1992). Westlund sammenlignet vekt ved første og andre undersøkelse (3-5 år imellom) blant middelaldrende norske menn og kvinner i 3 norske fylker, og fant en klar assosiasjon mellom vektreduksjon og nedgang i blodtrykk og i plasmakonsentrasjon av kolesterol og triglyserider. Vektendringen var av signifikant betydning for reduksjonen i nivået på disse risikofaktorene (National Health Screening Service, 1988).

I en oversiktsartikkel av 33 studier av assosiasjonen mellom moderat vekttap ( $10 \%$ eller mindre) og risikofaktorer for ulike sykdommer, konkluderer Goldstein (1992) med at personer med KMI > 30 som allerede har diabetes type II, hypertensjon eller hyperlipidemi, vil forbedre glukosekontroll, redusere blodtrykket og redusere kolesterolnivået, ved moderat vektreduksjon.

Man har estimert at en $10 \mathrm{~kg}$ nedgang i vekt tilsvarer et fall på $10 \%$ i totalkolesterol, $15 \%$ fall $\mathrm{i}$ LDL-kolesterol, 30\% fall i triglyserider og 8\% økning i HDL (Obesity in Scotland, 1996). Det gunstigste resultatet ble funnet hos dem med mye bukfedme (Hankey et al., 1995). 


\section{Kreft}

Dyrestudier har gjennomgående vist reduksjon i insidensen av kreft som et resultat av energirestriksjoner, men man vet ikke sikkert om dette skyldes lavere energiinntak eller lavere inntak av fett. Det er vanskelig å påvise lignende samvariasjoner i studier på mennesker (American Institute of Cancer Research, s. 367).

\section{Gallesten}

Kvinner som taper 4-10 kg har 44\% økt risiko for klinisk gallestenssykdom, og større vektreduksjon øker risikoen (WHO-report, 1998, s. 77). Premenopausale kvinner er spesielt utsatt. I en 8 års oppfølging i Nurses' Health Study (Stampfer et al., 1992) var det moderat økt risiko for gallesten blant dem som nylig hadde redusert vekten, justert for KMI før vekttapet. Siden det også er assosiasjon mellom fedme og gallesten, er det ikke alltid lett å vite om det er fedmen eller vektreduksjonen som ligger bak utviklingen av gallesten.

\section{Respirasjonssykdom}

I studien av Syvendedags adventister fant Singh og Lindsted (1998) at vekttap var assosiert med økt dødelighet av respirasjonssykdom i gruppen med stabil vekt og uten slik sykdom ved starten av studien, i forhold til personer med stabil/økt vekt.

\section{Osteoporose og brudd}

Norske kvinner som tapte $>3 \mathrm{~kg}$ i en 3-5 årsperiode hadde økt risiko for lårhalsbrudd $(\mathrm{RR}=2,1)$ (gjennomsnittlig 11,3 år etter siste screening, Meyer et al., $1995 b)$. Det var samme mønster for menn $(R R=3,4)$. Justering for alvorlig kreft, røyking og fysisk aktivitet endret ikke hovedfunnene.

Også analyser av lårhalsbrudd fra NHANES I (1971/75-92, Mussolino et al., 1998) av nær 3000 hvite menn (45-74 år ved baseline) ga $R R=2,3$ for lårhalsbrudd ved vektreduksjon på $10 \%$ eller mer, kontrollert for andre variable - inkludert flere kroniske sykdommer.

Joakimsen (1998) fant, i motsetning til andre (Meyer et al., 1995b; 1999; Ensrud et al., 1997b), ingen assosiasjon mellom lårhalsbrudd - og vekttap eller vektfluktuasjon blant menn og kvinner i Tromsø mellom 1980 og 1987.

Eldre menn som gikk ned $\geq 10 \%$ i vekt fra 50 -års alder hadde en signifikant økt risiko for lårhalsbrudd $(R R=1,85)$ - justert for en rekke konfunderende variable - bl.a alder, røyking, KMI ved baseline og antall medisinske tilstander (Langlois et al., 1998).

En analyse av kvinnene i samme studie ga samme funn som for menn (Langlois et al., 1996). Vekttap på $\geq 10 \%$ ga $\mathrm{RR}=2,9$ etter justering, mens vekttap på $5-9,9 \%$ ga $\mathrm{RR}=1,6$ (KI 0,98-2,6).

I en amerikansk studie av eldre kvinner fant man også økt risiko for lårhalsbrudd og andre "frailty" frakturer - unntatt kompresjonsfrakturer, med økende vekttap (Ensrud et al., 1997b). Etter justering for en rekke konfunderende variable var $\mathrm{RR}=1,68$ for hver $10 \%$ nedgang i vekt.

Det er flere studier som bekrefter at vektreduksjon samvarierer med redusert bentetthet, og at man finner en økning i bentetthet etter vektøkning (Nguyen et al., 1998).

\section{Leddsykdommer}

Den vitenskapelige dokumentasjonen av effekten av vektreduksjon ved artrose, artritt, podagra og andre leddsmerter er sparsom. Èn studie har vist at personer med kraftig fedme som gjennomgikk kirurgisk behandling, med etterfølgende vektreduksjon på $44 \mathrm{~kg}$, fikk redusert sine leddsmerter i betydelig grad (Andersen et al., 1998, s. 185). I en befolkningsundersøkelse medførte vekttap hos personer med fedme, en redusert risiko for å utvikle artrose i kneleddet med 25-33\% (Andersen et al., 1998, s. 185/186).

\section{Psykososiale konsekvenser}

Vi har lite kunnskap om psykososiale følger av slanking og moderat vektreduksjon (WHO-report, 1998, s. 76), men en relativt ny studie har vist selvrapportert bedring i livskvalitet etter å ha vedlikeholdt sitt vekttap over ett år (Klem et al., 1997). Vi vet imidlertid ingen ting om dem som mislyktes $\mathrm{i}$ å gå ned $\mathrm{i}$ vekt $\mathrm{i}$ denne studien. Det er videre vist positive effekter på livskvalitet etter kirurgisk vektreduksjon (Rand og MacGregor, 1991; Sjöström et al., 1995).

På den annen side er det vist at slankeatferd kan være assosiert med redusert livskvalitet. Seidell et al. (1986) fant $i$ en oppfølgingsstudie at slankeatferd blant kvinner var relatert til helseplager, uavhengig av graden av overvekt. Man fant videre at både de som var normalvektige ved oppfølgingen og de som fortsatt var overvektige, hadde like mye helseplager - og mere plager enn normalvektige i utgangspunktet.

\section{VEKTFLUKTUASJON}

Vektfluktuasjon (weight cycling) er definert forskjellig i ulike studier, noe som skaper problemer når man skal sammenligne og konkludere (National Task Force, 1994). I likhet med f.eks. French et al. (1997) har Meyer et al. (1998) definert vektfluktuasjon som standardavviket rundt den estimerte regresjonslinjen, mens French et al. (1999) brukte vekttap på $\geq 9 \mathrm{~kg} 3$ ganger eller mer i løpet av 5 år som definisjon på alvorlig vektfluktuasjon.

Flere studier har rapportert at vektfluktuasjon er en selvstendig risikofaktor for hjerte-karsykdom og død, uavhengig av vekt og endring i vekt (Hamm et al., 1989; Lissner et al., 1989; 1991).

\section{Dodelighet}

I en studie fant man $\mathrm{RR}=1,8$ for død av kardiovaskulær sykdom blant middelaldrende menn som hadde minst $10 \%$ vektøkning og minst $10 \%$ vekttap i løpet av 25 år - sammenlignet med dem med relativt stabil vekt 
- etter justering for en rekke risikofaktorer, inkludert KMI (Hamm et al. 1989) (tabell 1).

Lissner et al (1991) fant etter 14 års oppfølging i Framingham-studien, at de med størst vektfluktuasjon hadde 1,3-2,0 høyere RR for totaldød og for død av koronar hjertesykdom, sammenlignet med dem med minst vektfluktuasjon.

I Honolulu Heart Study fant man (Iribarren et al., 1995) at de med størst vektfluktuasjon hadde økt risiko for totaldød $(\mathrm{RR}=1,25)$, død av kardiovaskulære sykdommer $(\mathrm{RR}=1,41)$ og ikke-kreft/ikke-kardiovaskulær død $(R R=1,53)$. Denne sammenhengen var imidlertid ikke til stede blant friske, ikke-røykende menn.

I Iowa Women's Health Study ble kvinner spurt om vekt ved 18, 30, 40 og 50 år og nåværende vekt, samt hvor mange ganger de hadde foretatt tilsiktet/ ønsket vektreduksjon på $\geq 9,1 \mathrm{~kg}$ siden 18 -årsalderen (French et al., 1997; 1999). Det var ingen assosiasjon mellom dødelighet og det å ha minst en slik episode med frivillig vektreduksjon (French et al., 1999). Derimot hadde kvinner med minst èn vektreduksjon som ikke var tilsiktet, opptil 57\% høyere total dødelighet i forhold til dem uten forsøk på vektreduksjon - og opptil 114\% høyere dødelighet av kardiovaskulære sykdommer.

I en multisenterstudie av menn med høy risiko for koronar hjertesykdom, viste man at personer i den høyeste kvartil av vektvariasjon ("intrapersonal standard deviation of weight") hadde $R R=1,64$ for totaldød i forhold til dem i laveste kvintil (Blair et al., 1993). Det var samme mønster for kardiovaskulær død. Assosiasjonen var imidlertid ikke til stede blant mennene med høyest KMI.

\section{Sykelighet og risikofaktorer}

Man fant i den samme studien som nevnt over, at økende vektvariasjon samvarierte med økt risiko for hjerteinfarkt, slag, diabetes og lårhalsbrudd (French et al., 1997). Justert for alder og KMI var risikoen følgende for den høyeste vs. laveste kvintil av vektfluktuasjon ("root mean square error around the slope of weight on age"): $R R=2,03$ for hjerteinfarkt, 1,61 for slag, 1,42 for diabetes, 0,85 for brystkreft, 0,88 for livmorkreft, 1,70 for lungekreft, 0,93 for annen kreft og 1,45 for lårhalsbrudd.

Meyer et al. (1998) studerte samvariasjon mellom vektfluktuasjon og lårhalsbrudd blant 39000 middelaldrende personer fra 3 fylker i Norge (gjennomsnittlig 11,6 års oppfølging etter screening - 3 målepunkter for hver person). Vektfluktuasjon økte risikoen for lårhalsbrudd - også etter eksklusjon av dem som hadde ulike sykdommer - og etter justering for KMI og konfunderende variable - bl.a. fysisk aktivitet. Det var spesielt stor økning i RR blant dem som var i den laveste halvdel av KMI. De av disse som varierte mest i vekt hadde en $\mathrm{RR}=4,40$ for lårhalsbrudd for menn og 2,42 for kvinner sammenlignet med dem som varierte minst. Hvis alle hadde hatt samme fluktuasjon som den laveste $1 / 4$, ville lårhalsbruddraten (aldersjustert) blitt redusert med nærmere $40 \%$ for begge kjønn.

Field et al. (1999) fant økt risiko for hypertensjon blant kvinner i Nurses' Health Study II som hadde slanket seg $\geq 9 \mathrm{~kg} 3$ ganger eller mer i løpet av en 4årsperiode $(\mathrm{RR}=2,94) \mathrm{og}$ blant dem som slanket $\mathrm{seg} \geq$ $4,5 \mathrm{~kg} 3$ ganger eller mer $(\mathrm{RR}=1,89)$. Den økte risikoen ble imidlertid ikke-signifikant etter justering for KMI ved utgangspunktet, vektendring i perioden og enkelte konfunderende variable.

Blant 153 overvektige personer, som ble fulgt i en 30-månedersperiode, fant man ingen sammenheng mellom vektfluktuasjon og kardiovaskulære risikofaktorer (Wing et al., 1995), men en reduksjon i risikofaktorene for hjerte-karsykdom etter vektreduksjon og en økning i risikofaktorene etter vektøkning.

I en "pasient-kontroll" studie av 114 diabetikere av hvert kjønn ( $\geq 50$ år ved utgangspunktet i 1984-1987), fant man signifikant økt risiko for utvikling av diabetes type II $(R R=1,7)$ ved vektfluktuasjon på $\geq 5 \mathrm{~kg}$ mellom 40 og 60 år - sammenlignet med dem uten vektfluktuasjon, kontrollert for alder, røyking med mer (Holbrook et al., 1989).

En gjennomgang av 43 studier mht. vektfluktuasjon konkluderer med at det ennå ikke er klare bevis for at dette har skadelige effekter på kroppsammensetning, energiomsetning, risikofaktorer for hjerte-karsykdom eller forutsetninger for å gå ned i vekt (National Task Force, 1994). De konkluderer med at vektfluktuasjon kan gi opphav til psykologiske problemer. De mener at man ikke kan konkludere ut fra de studiene som viser assosiasjon mellom vektfluktuasjon og død, fordi de ikke har greid å skille mellom frivillig og ufrivillig vekttap. De peker også på problemet med stor variasjon i definisjonen av "vektfluktuasjon". De ser ingen grunn til at man ikke skal anbefale en moderat vektreduksjon for personer med fedme, og de poengterer viktigheten av å forberede forebygging av vektoppgang når man starter vektreduksjonsregimer.

Når det gjelder psykososiale konsekvenser av vektfluktuasjon, er det gjort svært få studier. En mindre studie av 130 kvinner med fedme som hadde slanket seg gjennomsnittlig 4,7 ganger, viste ingen sammenheng mellom slanking og økt forekomst av depresjon eller andre psykiske problemer (Bartlett et al., 1996).

\section{VEKT-HELSE PARADOKSET}

Det er lansert flere forklaringer på hvorfor de gunstige resultatene av vekttap på risikofaktorer for kardiovaskulær sykdom og diabetes ikke gjenspeiles i redusert sykelighet og dødelighet. Pietrobelli et al. (1998) foreslår at det kanskje er forskjell mellom tap av kroppsfett og tap av vekt. De reanalyserte data fra to studier og fant at tap av kroppsfett førte til lavere total dødelighet $(\mathrm{OR}=0,97$ og $\mathrm{OR}=0,83 \mathrm{i}$ de 2 studiene $)$, mens vekttap førte til økt dødelighet $(\mathrm{OR}=1,02$ og $\mathrm{OR}=1,06)$ (målt ved hhv. hudfoldtykkelse og vekttap i kg). Kan- 
skje er det slik at ordinær vektreduksjon i det vesentlige medfører tap av muskler - og ikke tap av fettvev?

I sin omfattende oversikt over studier av sammenhengen mellom vekttap og død, lanserer Gaesser (1999) andre mulige forklaringer. Han viser til flere studier som finner at lav-karbohydrat-dietter kan føre til ugunstig kolesterolprofil - og at slike dietter også øker inntak av animalske produkter. Han trekker også frem studier som viser at vektreduksjon fører til reduksjon av konsentrasjonen av alpha-linolensyre i serum, hvilket igjen kan føre til økt risiko for atherosklerose. De negative konsekvensene av vektreduksjon kan også være knyttet til bruk av slankemedikamenter - som kan føre til økt risiko for primær lungehypertensjon og sykdom i hjerteklaffene (Gaesser, 1999).

Ytterligere en forklaring kan være at man ikke tar hensyn til vektfluktuasjon i mange studier av vektreduksjon - en faktor som kan ha en selvstendig og uavhengig effekt på sykelighet og dødelighet. Vektfluktuasjon er imidlertid vanskelig å definere - og er definert forskjellig i ulike studier.

Williamson (1999) trekker frem at det kan være at frivillig vekttap og dens ledsagende fysiologiske gunstige effekter ofte er kortvarige - og at resultatene fra større observasjonsstudier, som ikke viser noen dødelighetsnedgang etter frivillig vektnedgang, faktisk er riktige.

Enkelte fremfører at observasjonsstudier er av liten eller ingen verdi mht. å besvare spørsmålet om helsekonsekvensene av frivillig vekttap (Kuller, 1999). Det er åpenbart at slike studier har metodiske svakheter slik som f.eks. vanskeligheter med

1. å måle vedlikehold av vekttap over lang tid.

2. å skille mellom frivillig og ufrivillig vekttap. Ufrivillig vekttap kan reflektere underliggende sykdom.

3. å skille den effekten vekttapet har per se, fra endringer i kosthold og fysisk aktivitet som er nødvendig for å redusere vekten, og som skjer samtidig.

4. å kontrollere for røyking. Mange studier har ikke kontrollert for eller ikke stratifisert på røyking.

5. å kontrollere for mellomliggende variable som kolesterolnivå og blodtrykk. Disse er trolig resultat av vektendring - og bør ikke kontrolleres for.

Kuller (1999) mener på denne bakgrunn at man bare kan få svar på spørsmålet om helseeffektene av slanking ved å gjennomføre randomiserte kliniske forsøk (RCT). Spørsmålet er om slike RCT, hvis de overhode lar seg gjennomføre, vil kunne besvare spørsmålet om vektnedgang reduserer dødeligheten. Det er f.eks. høyst usikkert om det er mulig å finne en representativ gruppe som er villig til å delta $\mathrm{i}$ en slik studie over mange år. Det er også mange etiske og metodiske problemer forbundet med denne type studier - f.eks.: Hva gjør man med dem som prøver, men ikke greier å redusere vekten? Hva gjør man med dem som går opp igjen i vekt senere? Hvilket tilbud skal alle de overvektige personene i kontrollgruppen få i alle disse årene? Skal de ha lov til å prøve å redusere vekten? Og hvor spesielle er de individene man sitter igjen med i kontroll- og intervensjonsgruppen etter mange års studie?

Williamson og Pamuk (1993) anbefaler godt designede observasjonsstudier for å avdekke helsekonsekvensene av frivillig vekttap, da de ikke tror det er mulig å gjennomføre noen RCT av vektreduksjon - med sykelighet og dødelighet som endepunkter.

\section{SAMMENFATNING}

Gaesser (1999) konkluderer i sin oversikt over studier av vekttap og dødelighet at det ikke finnes noe bevis for at vektreduksjon blant friske overvektige personer reduserer dødeligheten. Han mener også det er unødvendig med spesifikke vektråd til personer med en eller flere vektrelaterte sykdommer - fordi: 1) reduksjonen i dødelighet assosiert med frivillig vekttap er uavhengig av hvor mye man går ned i vekt, 2) reduksjonen $\mathrm{i}$ dødelighet assosiert med økt fysisk aktivitet (23-24\%), uavhengig av vektendring, er større enn reduksjonen ved vektreduksjon $(20 \%)$, og 3 ) mange vektrelaterte risikofaktorer og sykdommer kan forbedres uavhengig av vekttap. I lys av den potensielle risiko man løper ved slanking og vektfluktuasjon, bør helsetjenesten, etter Gaessers mening, fokusere mer på endringer i livsstil - spesielt på sunnere kost og fysisk aktivitet, enn på slanking per se.

Gaessers konklusjoner er langt på vei sammenfallende med rådene fra the Canadian Task Force on Preventive Health Care (Douketis et al., 1999). Etter en meget grundig gjennomgang av litteraturen når det gjelder forebygging og behandling av overvekt, bl.a. med eksklusjon av studier som metodemessig ikke holdt mål, konkluderer de med følgende: 1) Det finnes ikke tilstrekkelig kunnskap til å gi råd - hverken for eller mot - befolkningsbasert forebygging av fedme. 2) Pga. helsekonsekvensene av fedme og den begrensede langtidseffekt man har funnet når det gjelder ulike slankemetoder, bør helsepersonell imidlertid satse på å forebygge fedme overfor enkeltpersoner. 3) For voksne personer med fedme uten vektrelaterte sykdommer, er det ikke tilstrekkelig kunnskap til å anbefale/ikke anbefale slanking pga. manglende langtidseffekt av ulike slankemetoder. 4) For voksne personer med fedme med vektrelaterte sykdommer (f.eks. diabetes type II og hypertensjon) er slanking anbefalt fordi det kan lindre symptomer og redusere behovet for medikamenter for de sykdommene de har, i det minste på kort sikt.

Fordi det har vist seg vanskelig for personer med fedme å redusere vekten permanent, og fordi resultatene mht. helseeffektene av vektreduksjon er usikre, bør hovedinnsatsen settes inn i forhold til å forebygge overvekt/fedme i den norske befolkning - samt oppmuntre til økt fysisk aktivitet og et sunnere kosthold. Blant personer med vektproblemer kan det være et 
viktig mål å forebygge ytterligere vektøkning gjennom endrede kost- og mosjonsvaner. Inntil videre synes det som konklusjonen i lederartikkelen i New England Journal of Medicine i 1998 fortsatt er gyldig: "Unfortunately, the data linking overweight and death, as well as showing the beneficial effects of weight loss, are limited, fragmentary, and often ambiguous. Until we have better data about the risks of being overweight and the benefits and risks of trying to lose weight, we should remember that the cure for obesity may be worse than the condition" (Kassirer og Angell, 1998).

Arbeidet med litteraturgjennomgangen er støttet av Statens råd for ernæring og fysisk aktivitet.

\section{REFERANSER}

Andersen T, Rissanen A, Rössner S (red). Fetma/fedme - en nordisk lärobok. Stockholm: Studentlitteratur, 1998.

American Institute of Cancer Research. Food, nutrition and the prevention of cancer: a global perspective. Washington: World Cancer Research Fund. American Institute of Cancer Research, 1997: 1-670.

Andres R, Muller DC, Sorkin JD. National Institutes of Health technology assessment conference: Long term effects of change in body weight on all-cause mortality: a review. Ann Intern Med 1993; 119 (Suppl): 737-43.

Ballard-Barbash R, Schatzkin A, Taylor PR, Kahle LL. Association of change in body mass with breast cancer. Cancer Res 1990; 50: 2152-5.

Bartlett SJ, Wadden TA, Vogt RA. Psychosocial consequences of weight cycling. J Consult Clin Psychol 1996; 64: 587-92.

Blair SN, Brodney S. Effects of physical inactivity and obesity on morbidity and mortality: current evidence and research issues. Med Sci Sports Exerc 1999; 31 (11 Suppl): S646-62.

Blair SN, Shaten J, Brownell K, Collins G, Lissner L. Body weight change, all-cause mortality, and cause-specific mortality in the Multiple Risk Factor Intervention Trial. Ann Intern Med 1993; 119: 749-57.

Calle EE, Thun MJ, Petrelli JM, Rodriguez C, Heath CW Jr. Body-mass index and mortality in a prospective cohort of U.S. adults. N Engl J Med 1999; 341: 1097-105.

Colditz GA, Willett WC, Rotnitzky A, Manson JAE. Weight gain as a risk factor for clinical diabetes mellitus in women. Ann Intern Med 1995; 122: 481-6.

Diehr P, Bild DE, Harris TB, Duxbury A, Siscovick D, Rossi M. Body mass index and mortality in non-smoking older adults: The Cardiovascular Health Study. Am J Public Health 1998; 88: 623-9.

Douketis JD, Feightner JW, Attia J, Feldman WF. Periodic health examination, 1999 update: 1. Detection, prevention and treatment of obesity. Canadian Task Force on Preventive Health Care. CMAJ 1999; 160: 513-25.

Ensrud KE, Lipschutz RC, Cauley JA, Seeley D, Nevitt MC, Scott J, Orwoll ES, Genant HK, Cummings SR for the study of Osteoporotic Fractures Research Group. Body size and hip fracture risk in older women: a prospective study. Study of osteoporotic fractures research group. Am J Med 1997a; 103: 274-80.

Ensrud KE, Cauley J, Lipschutz R, Cummings SR. Weight change and fractures in older women. Study of osteoporotic fractures research group. Arch Intern Med 1997b, 157: 857-63.

Eriksson K-F, Lindgärde F. Prevention of Type 2 (non-insulin-dependent) diabetes mellitus by diet and exercise. The 6-year Malmö feasibility study. Diabetologia 1991; 34: 891-8.

Field AE, Byers T, Hunter DJ, Laird NM, Manson JE, Williamson DF, Willett WC, Colditz GA. Weight cycling, weight gain, and risk of hypertension in women. Am J Epidemiol 1999: 150: 573-9.

Ford ES, Williamson DF, Liu S. Weight change and diabetes incidence: Findings from a National cohort of US adults. Am J Epidemiol 1997; 146; 214-22.

French SA, Folsom AR, Jeffery RW, Zheng W, Mink PJ, Baxter JE. Weight variability and incident disease in older women: the Iowa Women's Health Study. Int J Obes Relat Metab Disord 1997; 21: 217-23

French SA, Folsom AR, Jeffery RW, Williamson D. Prospective study of intentionality of weight loss and mortality in older women: The Iowa Women's Health Study. Am J Epidemiol 1999; 149: 504-14.

Gaesser GA. Thinness and weight loss: beneficial or detrimental to longevity? Med Sci Sports Exerc 1999; 31: 1118-28.

Goldstein DJ. Beneficial health effects of modest weight loss. Int J Obesity 1992; 16: 397-415.

Gunnes M, Lehmann EH, Mellstrom D, Johnell O. The relationship between anthropometric measurements and fractures in women. Bone 1996; 19: 407-13.

Hamm P, Shekelle RB, Stamler J. Large fluctuations in body weight during young adulthood and twenty-five-year risk of coronary deaths in men. Am J Epidemiol 1989; 129: 312-8.

Hankey CR, Rumley A, Lowe GDO, Lean MEJ. Weight loss improves established indices of ischaemic heart disease risk. Proc Nutr Soc 1995; 54: 94A.

Higgins M, D’Agostino R, Kannel W, Cobb J. National Institutes of Health Technology Assessment Conference: Benefits and adverse effects of weight loss: Observations from the Framingham study. Ann Intern Med 1993; 
119 (Suppl); 758-63.

Holbrook TL, Barrett-Connor E, Wingard DL. The association of lifetime weight and weight control patterns with diabetes among men and women in the adult community. Int J Obes 1989; 13: 723-9.

Huang, Z, Hankinson SE, Colditz GA, Stampfer MJ, Hunter DJ, Manson JAE, et al. Dual effects of weight and weight gain on breast cancer risk. JAMA 1997; 278: 1407-11.

Irribarren C, Sharp DS, Burchfiel CM, Petrovitch H. Association of weight loss and weight fluctuation with mortality among Japanese American men. N Engl J Med 1995; 333: 686-92.

Jamison RN, Stetson B, Sbrocco T, Parris WC. Effects of significant weight gain on chronic pain patients. Clin $J$ Pain 1990; 6: 47-50.

Joakimsen RM, Fønnebø V, Magnus JH, Tollan A, Søgaard AJ. The Tromsø study: Body height, body mass index and fractures. Osteoporose Int 1998; 8: 436-42.

Kassirer JP, Angell M. Losing weight - an ill-fated New Year's resolution. N Eng J Med 1998; 338: 52-4.

Klem ML, Wing RR, McGuire MT, Seagle HM, Hill JO. A descriptive study of individuals successful at longterm weight maintenance of substantial weight loss. Am J Clin Nutr 1997; 66: 239-46.

Klesges RC, Klem ML, Klesges LM. The relationship between changes in body weight and changes in psychosocial functioning. Appetite 1992; 19: 145-53.

Kuller LW. Invited commentary on "Prospective study of intentionality of weight loss and mortality in older women: The Iowa Women's Health Study" and "Prospective study of intentional weight loss and mortality in overweight white men aged 40-64 years". Am J Epidemiol 1999; 149: 515-6.

Kushner RF. Body weight and mortality. Nutr Rev 1993; 51: 127-36.

Langlois JA, Harris T, Looker AC, Madans J. Weight change between age 50 years and old age is associated with risk of hip fracture in white women aged 67 years and older. Arch Intern Med 1996; 156: 989-94.

Langlois JA, Visser M, Davidovic LS, Maggi S, Li G, Harris TB. Hip fracture risk in older white men is associated with change in body weight from age 50 years to old age. Arch Intern Med 1998; 158: 990-6.

Le Marchand, Kolonel LN, Earl ME, Mi MP. Body size at different periods of life and breast cancer risk. Am J Epidemiol 1988; 128: 137-52.

Lean ME, Powrie JK, Anderson AS, Garthwaite PH. Obesity, weight loss and prognosis in type 2 diabetes. Diabet Med 1990; 7: 228-33.

Lee IM, Paffenbarger RS Jr. Change in body weight and longevity. JAMA 1992; 268: 2045-9.

Lee IM, Paffenbarger RS Jr. Is weight loss hazardous? Nutr Rev 1996; 54: S116-24.

Lissner L, Bengtsson C, Lapitus L, Larsson B, Bengtsson B, Brownell K. Body weight variability and mortality in the Gothenburg Prospective Studies on men and women. In: Björntorp P, Rossner S, eds. Obesity in Europe 88: Proceedings of the First European Congress on Obesity. London, England: Libbey: 1989: 55-60.

Lissner L, Odell PM, D’Agostino RB, Stokes J, Kreger BE, Belanger AJ, et al. Variability of body weight and health outcomes in the Framingham population. N Engl J Med 1991; 324: 1839-44.

Losonczy KG, Harris TB, Cornoni-Huntley J, Simonsick EM, Wallace RB, Cook NR, Ostfeld AM, Blazer DG. Does weight loss from middle age to old age explain the inverse weight mortality relation in old age? $\mathrm{Am} \mathrm{J}$ Epidemiol 1995; 141: 312-21.

Magnusson C, Baron J, Persson I, Wolk A, Bergstrom R, Trichopoulos D, Adami HO. Body size in different periods of life and breast cancer risk in post-menopausal women. Int J Cancer 1998; 76: 29-34.

Manson JE, Stampfer MJ, Hennekens CH, Willett WC. Body weight and longevity. A reassessment. JAMA 1987; 257: 353-8.

Manson JAE, Willett WC, Stampfer MJ, Colditz GA, Hunter DJ, Hankinson SE, Hennekens CH, Speizer FE. Body weight and mortality among women. $N$ Engl J Med 1995; 333: 677-85.

Meyer HE, Falch JA, O'Neill T, Tverdal A, Varlow J. Height and body mass index in Oslo, Norway, compared to other regions of Europe: Do they explain differences in the incidence of hip fracture? European Vertebral Osteoporosis Study Group. Bone 1995a; 17: 347-50.

Meyer HE, Tverdal A, Falch JA. Changes in body weight and incidence of hip fracture among middle aged Norwegians. BMJ 1995b; 311: 91-2.

Meyer HE, Tverdal A, Selmer R. Weight variability, weight change and the incidence of hip fracture: A prospective study of 39000 middle-aged Norwegians. Osteoporos Int 1998: 8; 373-8.

Mikkelsen KL, Heitmann BL, Keiding N, Sørensen TIA. Mortality risk associated with body weight is conveyed both the attained level and by the preceding weight change. Int J Obesity 1998; 22 (Suppl 3): S11.

Mussolino ME, Looker AC, Madans JH, Langlois JA, Orwoll ES. Risk factors for hip fracture in white men: the NHANES I Epidemiologic follow-up Study. J Bone Miner Res 1998; 13: 918-24.

Must A, Jaques PF, Dallal GE, Bajema CJ, Dietz WH. Long-term morbidity and mortality of overweight adolescents. A follow-up of the Harvard Growth Study of 1922 to 1935. N Eng J Med 1992; 327: 1350-5.

National Health Screening Service. The cardiovascular disease study in Norwegian counties. Results from second screening. National Health Screening Service, Oslo, 1988. 
National Task Force on the Prevention and Treatment of Obesity. Weight cycling. JAMA 1994: 272: 1196-202.

Nguyen TV, Sambrook PN, Eisman JA. Bone loss, physical activity, and weight change in elderly women: the Dubbo osteoporosis epidemiology study. J Bone Miner Res 1998; 13: 1458-67.

Obesity in Scotland. Integrating prevention with weight management. A national clinical guideline recommended for use in Scotland. Edinburgh, Scottish Intercollegiate Guidelines Network, 1996.

Paffenbarger RS Jr, Hyde RT, Wing AL, Hsieh CC. Physical activity, all-cause mortality, and longevity of college alumni. N Engl J Med 1986; 314: 605-13.

Pamuk ER, Williamson DF, Madans J, Serdula MK, Kleinman JC, Byers T. Weight loss and mortality in a national cohort of adults 1971-1987. Am J Epidemiol 1992; 136: 686-97.

Pamuk ER, Williamson DF, Serdula MK, Madans J, Byers TE. Weight loss and subsequent death in a cohort of U.S. adults. Ann Intern Med 1993; 119: 744-8.

Pietrobelli A, Faith MS, Heo M, Heymsfield SB, Allison DA. Fat-loss decreases and weight-loss increases allcause mortality: results from two epidemiologic studies. Int J Obesity 1998; 22 (Suppl 3): S11.

Rand CSW, MacGregor AMC. Successful weight loss following obesity surgery and the perceived liability of morbid obesity. Int J Obesity 1991; 15: 577-9.

Rexrode KM, Hennekens CH, Willett WC, Colditz GA, Stampfer MJ, Rich-Edwards JW, Speizer FE, Manson JE. A prospective study of body mass index, weight change, and risk of stroke in women. JAMA 1997; 277: 153945 .

SEF-rapport. Statens råd for ernæring og fysisk aktivitet. Vekt-helse. Rapport nr. 1/2000. Oslo: Statens råd for ernæring og fysisk aktivitet, 2000.

Seidell JC, Bakx KC, Deurenberg P, Burema J, Hautvast JG, Huygen FJ. The relation between overweight and subjective health according to age, social class, slimming behavior and smoking habits in Dutch adults. $A m J$ Public Health 1986; 76: 1410-5.

Singh RB, Niaz MA, Ghosh S, Singh R, Rastogi SS. Effect on mortality and reinfarction of adding fruits and vegetables to a prudent diet in the Indian experiment of infarct survival (IEIS). $J$ Am Coll Nutr 1993; 12: 255-61.

Singh PN, Lindsted KD. Body mass and 26-year risk of mortality from specific diseases among women who never smoked. Epidemiology 1998; 9: 246-54.

Sjöström L, Narbro K, Söström D. Costs and benefits when treating obesity. Int J Obes Relat Metabol Dis 1995; 19 (Suppl): 9-12.

Solomon CG, Manson JE. Obesity and mortality: a review of the epidemiologic data. Am J Clin Nutr 1997; 66 (4 Suppl): 1044S-50S.

Stampfer MJ, Maclure KM, Colditz GA, Manson JAE, Willett WC. Risk of symptomatic gallstones in women with severe obesity. Am J Clin Nutr 1992; 55: 652-8.

Stevens J, Cai J, Pamuk ER, Williamson DF, Thun MJ, Wood JL. The effect of age on the association between body-mass index and mortality. N Engl J Med 1998a; 338: 1-7.

Stevens J, Tyroler HA, Cai J, Paton CC, Folsom AR, Tell GS, Schreiner PJ, Chambless LE. Body weight change and carotid artery wall thickness. The Atherosclerosis Risk in Communities (ARIC) Study. Am J Epidemiol 1998b; 147: 563-73.

Willett WC, Manson JAE. Stampfer MJ, Colditz GA, Rosner B, Speizer FE, Hennekens CH. Weight, weight change, and coronary heart disease in women. Risk within the "normal" weight range. JAMA 1995; 273: 461-5.

Willett WC, Dietz WH, Colditz GA. Guidelines for healthy weight. $N$ Engl J Med 1999; 341: 427-34.

Williamson DF. Weight loss and mortality in persons with type-2 diabetes mellitus: a review of the epidemiological evidence. Exp Clin Endocrinol Diabetes 1998; 106 (Suppl 2): 14-21.

Williamson DF. Dr. Williamson responds to dr. Kuller. Am J Epidemiol 1999; 149: 517-8.

Williamson DF, Pamuk ER. The association between weight loss and increased longevity. A review of the evidence. Ann Intern Med 1993; 119: 731-6.

Williamson DF, Pamuk E, Thun M, Flanders D, Byers T, Heath C. Prospective study of intentional weight loss and mortality in never-smoking overweight us white women and aged 40-64 years. Am J Epidemiol 1995; 141: $1128-41$.

Williamson DF, Pamuk E, Thun M, Flanders D, Byers T, Heath C. Prospective study of intentional weight loss and mortality in overweight white men aged 40-64 years. Am J Epidemiol 1999; 149: 491-503.

Wing RR, Jeffery RW, Hellerstedt WL. A prospective study of effects of weight cycling on cardiovascular risk factors. Arch Intern Med 1995; 155: 1416-22.

WHO-report. Obesity. Preventing and managing the global epidemic. Report of a WHO Consultation on Obesity. Geneva, 3-5 June 1997. Geneva: World Health Organization, 1998.

Waaler HT. Height, weight and mortality: the Norwegian experience. Acta Med Scand 1984; 679 (Suppl): 1-56.

Yaari S, Goldbourt U. Voluntary and involuntary weight loss: associations with long term mortality in 9,228 middle-aged and elderly men. Am J Epidemiol 1998; 148: 546-55. 